Journal Home Page:

http://perlinguam.journals.ac.za
Per
A Journal for Language Learning Tydskrif vir Taalaanleer

\title{
ELICITING AND LADDERING PROSPECTIVE LANGUAGE TEACHERS' CLASSROOM-RELATED CONSTRUCTS
}

\author{
Willfred Greyling ${ }^{1}$ \\ Waikato Institute of Technology (Wintec), Hamilton, New Zealand
}

This article has a dual aim. First, the author reports on how two techniques were used from personal construct psychology, dyadic elicitation and laddering (Fransella, Bell \& Bannister, 2004:27-34, 39-43) to raise a cohort of prospective teachers' awareness of their classroomrelated constructs $(N=21)$. Second, the process for elicitation of the constructs depended on the trainees' ability to deal with the cognitive and the social-interactive demands of the elicitation tasks. These demands were enacted in a discursive process which conversation analysts refer to as 'sequential organisation'; in addition, participants followed the rules that govern sequence organisation typical of the interview (Schegloff, 2007: 231). Using 12 random combinations of 10 classroom-based scenarios, which served as elements for the elicitation process, the researcher elicited approximately 800 constructs from the group of prospective teachers. A matrix-based summary of 48 constructs elicited from 10 teachertrainees for the first scenario combination are presented. In addition, how one of the teachers responded to the full range of scenario-based elements is outlined briefly. The conclusion is drawn that the attaching of verbal labels to their meaning-making constituted deliberate and conscious thinking by prospective teachers about their experience, which is typical of awareness-raising activity. Moreover, the social-interactive demands of this interview type, requiring the prospective teachers to follow the rules of interaction in this context to explore and label their personally held constructs, served to reinforce the awareness-raising process. A further conclusion was that the matrix-based analysis was contentious: Although students may use the same labels to refer to a construct, the meanings they attach to those labels may vary.

\section{INTRODUCTION}

Like Freeman (2002:1), I argue that 'teachers' mental lives represent the hidden side of teaching' and that teacher education should focus on at least two socio-cognitive dimensions:

[o]ne involves the developmental question of how individuals learn to teach; the other involves the epistemological question of how teachers know what they know to do what they do (Freeman, 2002:1).

Given the wealth of research on teachers' belief systems and mental models (Borg, 2003; Freeman, 2002; Woods, 1996), I base my argument on the premise that

teachers are active, thinking decision-makers who make instructional choices by drawing on complex, practically-orientated, personalised, and contextsensitive networks of knowledge, thoughts and beliefs (Borg, 2003:81). 
Language teachers draw on their mental models or, in other terms, construct networks, when they create interactional spaces, define learner roles and structure language learning experiences in their classrooms. In this article, then, I report on the first stage $^{2}$ of a project aimed at developing a cohort of prospective language teachers' awareness of how, individually and collectively, they configured their classroom-related constructs in the final semester of their training. In brief, the reasoning was that perspectives and techniques from personal construct psychology could be used (Fransella, Bell \& Bannister, 2004:27-34, 39-43; Kelly, 1955: 46-104; Kelly, 1966/2003:3-20; Pope, 2003:303-310; Salmon, 2003:311-318;) to prompt the students to engage in deliberate and reflective analysis of their classroom experiences. It was only after I had applied the dyadic elicitation and laddering techniques and then reviewed the recorded interviews that I realised that the social-interactive demands of the trainer-trainee interviews reinforced the awareness-raising process. When the prospective teachers verbalised their constructs, they had to adhere to the rules that govern well-formed and appropriate contributions to the interview talk. This co-operative process required that they remain 'on task' and 'on topic' as they externalised their classroom-related constructs (White, 1995: 15) in 'talkabout-their-meaning' making. My approach was not only consistent with critical participatory loops in classroom-based research (Murphey \& Falout, 2010:811-821) but could also be tied to teachers' professional identity formation (Tsui, 2007:657-680).

In the rest of this article, the research methods, findings and conclusions are outlined.

\section{RESEARCH METHODS}

In this section, background on the target group and how the dyadic elicitation and laddering research methods can be used in an interview process to elicit the cohort's classroom-related constructs was provided. In addition, I show how, in a post-hoc review of the 21 trainertrainee interviews, I could use perspectives from conversation analysis to argue a case in support of the awareness-raising goals of the project.

The teacher-trainees, in their final year of teacher training, gave their collective consent to participate in the project, agreeing to assign $25 \%$ of their total mark for the course to their participation and contributions. As agreed with them, strict confidentiality in communicating about their contributions and constructs was maintained. Attention was focused on the target group's meaning making in a project which was embedded in their training, which meant that they were optimally motivated to remain engaged. The target group was composed of 14 Afrikaans-speaking, 4 English-speaking, and 3 Sesotho-speaking students. The group included 2 Afrikaans-speaking males and 1 Sesotho-speaking male. These prospective language teachers were headed for secondary school classrooms, teaching English as a second language. Following Kelly's individuality and sociality corollaries (Kelly, 1966/2003:9, 1417), the aim was to elicit these teachers' constructs for purposes of creating a repertory grid that would allow them to explore how their ratings would validate or disconfirm how they configured their individual networks of meaning (Fransella, Bell \& Bannister, 2004:13). Therefore, the focus in this article is on construct elicitation and laddering in the first phase of this project. The repertory grid results of the next phase are reported in Greyling (2011:167192).

Dyadic elicitation and laddering, developed by personal construct psychology practitioners $^{3}$, are premised on Kelly's dichotomy corollary (Fransella, 1989; Kelly, 1955:59- 
64) and his requirements for identifying constructs. He claimed that we develop mental models to anticipate the future ${ }^{4}$ and in this meaning-making process compare experiences for elements of similarity and difference:

If we choose an aspect in which $\mathrm{A}$ and $\mathrm{B}$ are similar, but in contrast to $\mathrm{C}$, it is important to note that it is the same aspect of all three, A, B and C, that forms the basis of the construct (Kelly, 1955:59).

Thus, a construct will have an aspect of similarity which forms the basis of an aspect of difference. For example, one may compare two experiences, concluding that they are similar because they are both instances of a participative approach to learning. However, they may be different because experience 1 involves a problem-based scenario and experience 2 a smallgroup, role-play exercise (an aspect of difference). For these two experiences, one may then choose verbal labels, such as those in the table directly below, to capture this interpretation:

Table 1: Example of a dichotomous construct

\begin{tabular}{|l|l|l|}
\hline $\begin{array}{l}\text { Aspect of difference } \\
\text { (Pole A) }\end{array}$ & Aspect of similarity & $\begin{array}{l}\text { Aspect of difference } \\
\text { (Pole B) }\end{array}$ \\
\hline Scenario-based & Participative learning & Small-group role-play-based \\
\hline
\end{tabular}

Thus, dyadic elicitation ${ }^{\mathbf{5}}$ is based on a comparative process, where the similarities and differences of two or more elements of an experience become the basis for defining a construct. Following Fransella, Bell and Bannister (2004:29-30), I adopted the following schema for the elicitation process, the words below capturing the verbal prompts used by the interviewer:

Step 1: Read the two scenarios of classroom events outlined on the two cards.

Step 2: How are these two scenarios the same or different?

If a difference is pointed out,

Step 3a: You have pointed out $\mathrm{X}$ as a difference; so what is its opposite?

Step 3b: For these opposites: what do they have in common?

If a similarity is pointed out,

Step 3c: For this aspect of similarity, how are the two scenarios different?

Laddering, as proposed by Hinkle (1965), may be used to explore the hierarchy of meanings associated with a teacher-trainee's preferred pole for any given construct. ${ }^{6}$ The following verbal prompts and schema for laddering were used (Fransella, Bell \& Bannister, 2004: 3940):

Step 1: Why did you prefer pole A to pole B of the construct?

Step 2: In response to the answer: Why is $\mathrm{X}$ (the answer) important to you?

Step 3: Iteratively: Why is the answer (Y) important to you? (Continue until the teacher-trainee is unable to produce more answers).

These two schemas served as points of orientation for the elicitation process. To record the teachers' constructs, note-taking, backed by recordings of the interviews, were used. For reasons of time, no transcribing of any of the recordings was done. However, when the discursive data ${ }^{7}$ to clarify the notes were reviewed, I sensed that the conversation-analytic 
notions of sequential and sequence organisation allowed me to describe the cognitive and social-interactive demands imposed by the interviews.

The two techniques represented schemas which required the trainer and the trainees to engage in a deliberate and conscious cognitive process of meaning making, followed by exchanges in which the prospective teachers were required to articulate their verbal labels for the constructs they had defined. Moreover, externalising their meaning making in an interview meant that they had to adhere to Grice's co-operative principle (Levinson, 1983:97-166; Mey, 1993:65;) in engaging the trainer. Trainer and trainee had to collaborate in producing a coherent and cohesive discourse, or what has been referred to as contingent interaction. At each 'transition relevance place' in the discourse, the next speaker, selected in the preceding turn, produces a personally relevant and coherent contribution which is intended to be on topic and on task (Van Lier, 1996:147-187).

Conversation analysts would be more specific, citing that the process of constructing an interactional exchange is a reciprocal process that evolves within a locally managed exchange system (Levinson, 1983:294-356; Mey, 1993:216-233; Ten Have, 2000:15-25), premised on three characteristics that require participants to remain on task consistently. The first of these is the notion within conversation analysis (CA) that while participants construct their talk, they align their contributions to the preceding talk, and in the majority of cases, to the immediately preceding turn-at-talk. This means that the current turn becomes the immediate context for generating the next turn. The second is that the 'current-speaker turn' frames the options for the relevant 'next-speaker action'. The third characteristic is that once the current speaker has elicited the next speaker turn, participants have a sense of their shared meanings in the emerging discourse and how well-formed the discourse is at that point. Thus, producing a joint discourse implies that participants are optimally committed to co-constructed meaning making within what Schegloff (2007:4) referred to as 'locally managed sequential organisation'. In addition, Schegloff (2007:231) argued that the participants have to follow the rules for interactional sequences across sections of turns so that they contribute appropriately to sequence organisation. The teacher-trainer, as the interviewer, is the superordinate in the authority relationship, who designs an interactional floor to organise the interviewing activities to meet the awareness-raising purposes of the project (Jones \& Thornborrow, 2004:399-423).

\section{FINDINGS AND DISCUSSION}

Some of the constructs elicited for the scenario combination 1 and 2 for 10 members of the group will be outlined in this section. In addition, one of the teacher's constructs for all the scenario pairings will be displayed. From an earlier constructivist study of a cohort of students' meaning making, related to the concept 'discursive initiative' (Greyling, 2008), it was apparent that a matrix-based analysis of teacher-trainees' verbal labels could be misleading. In the 2008 study, it was found that the same label, 'discursive initiative', elicited a wide range of related meanings. When students' explanations of the label were compared, it was clear that they had used individual configurations of meaning in the process. At best, students' meaning-making processes yielded similar meanings for some, but for others, individual, unrelated meanings. One would probably need a cognitive map of constructs, like the one proposed by Hill (1995), for each prospective teacher to extract similar and different meanings. 
In the midst of this individuality in meaning making (see endnote 8 for Kelly's individuality corollary) and elements of shared meaning (see endnote 9 for Kelly's commonality corollary), a conversation-analytic perspective was used to shed light on the interface between the cognitive and the social-interactive demands of the elicitation tasks.

\section{Constructs elicited and laddered}

In this stage of the project, the purpose was to elicit a significant number of constructs from which to select 12 in designing a repertory grid for rating the elements used in the constructs' elicitation. Thus, scenario pairings were employed to elicit constructs, and then at least one of the so-selected constructs per teacher in the group was laddered. The outcome was a list of constructs for each prospective teacher in the group. For the sake of space, a matrix to report on the constructs elicited for 10 teachers was prepared, thus restricting the summary to the first scenario pairing 1 and 2 (see Appendix A): 
Table 2: Matrix-based summary of 10 teacher-trainees' constructs for scenario pair $1 \&$ 2

\begin{tabular}{|c|c|c|c|c|c|c|c|c|c|c|c|}
\hline $\begin{array}{l}\text { CONSTRUCTS:SCENARIOS } 1 \text { AND } \\
2\end{array}$ & S1 & $\mathbf{S 2}$ & S3 & $\mathbf{S 4}$ & S5 & S6 & S7 & S8 & S9 & S10 & Tot \\
\hline 1. Inductive versus deductive learning & $\checkmark$ & & & & & & & & & & 1 \\
\hline $\begin{array}{l}\text { 2. Unprepared versus prepared learner } \\
\text { responses }\end{array}$ & $\checkmark$ & & & & $\checkmark$ & & & & & $\checkmark$ & 3 \\
\hline $\begin{array}{l}\text { 3. Teacher-learner versus learner- } \\
\text { learner created knowledge }\end{array}$ & $\checkmark$ & & & & & & & & & + & 1 \\
\hline $\begin{array}{l}\text { 4. Threatening versus non-threatening } \\
\text { conditions of learning }\end{array}$ & $\checkmark$ & & & $\checkmark$ & & & & & & & 2 \\
\hline $\begin{array}{l}\text { 5. Known-information versus open- } \\
\text { ended teacher questions }\end{array}$ & & $\checkmark$ & & & & & & & & & 1 \\
\hline $\begin{array}{l}\text { 6. Teacher-learner versus teacher- } \\
\text { prompted, learner-learner interaction }\end{array}$ & & $\checkmark$ & & & & & & & $\checkmark$ & & 2 \\
\hline $\begin{array}{l}\text { 7. Direct versus indirect strategies for } \\
\text { learning }\end{array}$ & & $\checkmark$ & & & & & & & & & 1 \\
\hline $\begin{array}{l}\text { 8. Transmission versus discovery } \\
\text { learning }\end{array}$ & & $\checkmark$ & & $\checkmark$ & $\checkmark$ & & & & & & 3 \\
\hline $\begin{array}{l}\text { 9. Explicit versus implicit forms of } \\
\text { learning }\end{array}$ & & $\checkmark$ & & & & & & & & & 1 \\
\hline $\begin{array}{l}\text { 10. Boring versus. fun/interesting ways } \\
\text { of learning }\end{array}$ & & $\checkmark$ & $\checkmark$ & & $\checkmark$ & & & & & & 3 \\
\hline $\begin{array}{l}\text { 11. Conscious versus subconscious } \\
\text { involvement in learning }\end{array}$ & & $\checkmark$ & & & & & & & & & 1 \\
\hline $\begin{array}{l}\text { 12. Irrelevant versus relevant } \\
\text { personalised learning }\end{array}$ & & $\checkmark$ & & $\checkmark$ & & & & & & & 2 \\
\hline $\begin{array}{l}\text { 13. Reduced versus increased learner } \\
\text { self-discovery }\end{array}$ & & $\checkmark$ & & & & & & & & & 1 \\
\hline $\begin{array}{l}\text { 14. Learners lacking versus having self- } \\
\text { confidence/self-esteem }\end{array}$ & & $\checkmark$ & & $\checkmark$ & & & $\checkmark$ & & & & 3 \\
\hline $\begin{array}{l}\text { 15. Superficial/artificial versus } \\
\text { spontaneous learner responses }\end{array}$ & & $\checkmark$ & & & $\checkmark$ & & & & & $\checkmark$ & 3 \\
\hline $\begin{array}{l}\text { 16. Teacher-centred versus learner- } \\
\text { centred approaches }\end{array}$ & & $\checkmark$ & & $\checkmark$ & & $\sqrt{2}$ & & $\checkmark$ & $\checkmark$ & $\checkmark$ & 6 \\
\hline $\begin{array}{l}\text { 17. Non-participatory vs. participatory } \\
\text { learning }\end{array}$ & & $\checkmark$ & & & & & & & & & 1 \\
\hline $\begin{array}{l}\text { 18. Stagnation versus growth in } \\
\text { classroom participants }\end{array}$ & & $\checkmark$ & & & & & & & & & 1 \\
\hline $\begin{array}{l}\text { 19. Less versus more involved in } \\
\text { teaching/learning }\end{array}$ & & $\checkmark$ & & & & & & & & & 1 \\
\hline $\begin{array}{l}\text { 20. Spontaneous versus considered } \\
\text { learner response }\end{array}$ & & & $\checkmark$ & & & & & & & & 1 \\
\hline $\begin{array}{l}\text { 21. Unpredictable versus predictable } \\
\text { learner responses }\end{array}$ & & & $\checkmark$ & & & & & & & & 1 \\
\hline $\begin{array}{l}\text { 22. Authentic versus inauthentic } \\
\text { language/learning }\end{array}$ & & & $\checkmark$ & & $\sqrt{ }$ & & & & & $\checkmark$ & 3 \\
\hline $\begin{array}{l}\text { 23. Ineffective versus effective } \\
\text { approaches to teaching }\end{array}$ & & & & $\checkmark$ & $\checkmark$ & $\checkmark$ & $\checkmark$ & & & & 4 \\
\hline $\begin{array}{l}\text { 24. Purposeless versus purposeful } \\
\text { learning }\end{array}$ & & & & $\checkmark$ & & & & & & & 1 \\
\hline 25. Insecure versus secure spaces for & & & & $\checkmark$ & & & & & & & 1 \\
\hline
\end{tabular}




\begin{tabular}{|c|c|c|c|c|c|c|c|c|c|c|c|}
\hline learners to learn & & & & & & & & & & & \\
\hline $\begin{array}{l}\text { 26. Real-life versus classroom } \\
\text { exchanges }\end{array}$ & & & & & $\checkmark$ & & & & & & 1 \\
\hline $\begin{array}{l}\text { 27. Structured versus constrained } \\
\text { freedom to learn }\end{array}$ & & & & & $\checkmark$ & & & & & & 1 \\
\hline $\begin{array}{l}\text { 28. Transformational versus traditional } \\
\text { learning }\end{array}$ & & & & & $\checkmark$ & & & & & & 1 \\
\hline $\begin{array}{l}\text { 29. More versus less efficient teaching } \\
\text { and learning }\end{array}$ & & & & & $\checkmark$ & $\checkmark$ & & & & & 2 \\
\hline $\begin{array}{l}\text { 30. Success versus failure of one's } \\
\text { approach }\end{array}$ & & & & & $\sqrt{ }$ & & & & & & 1 \\
\hline $\begin{array}{l}\text { 31. Sequenced versus unstructured } \\
\text { approach to learning }\end{array}$ & & & & & & $\checkmark$ & & & & & 1 \\
\hline $\begin{array}{l}\text { 32. Integrated versus fragmented } \\
\text { approach to learning }\end{array}$ & & & & & & $\checkmark$ & & $\checkmark$ & & & 2 \\
\hline $\begin{array}{l}\text { 33. Given versus withheld teacher } \\
\text { guidance }\end{array}$ & & & & & & $\checkmark$ & & & $\checkmark$ & $\checkmark$ & 3 \\
\hline 34. Liking versus not liking English & & & & & & $\checkmark$ & & & & & 1 \\
\hline $\begin{array}{l}\text { 35. Autonomous versus independent } \\
\text { learners }\end{array}$ & & & & & & & & & & & \\
\hline $\begin{array}{l}\text { 36. Having versus not having coping } \\
\text { skills }\end{array}$ & & & & & & $\checkmark$ & & & & $\checkmark$ & 2 \\
\hline 37. Passive versus active learners & & & & & & & $\checkmark$ & & & & 1 \\
\hline 38. No versus optimal improvement & & & & & & & $\checkmark$ & & & & 1 \\
\hline $\begin{array}{l}\text { 39. Learners eithher fail to or are able to } \\
\text { engage out of class }\end{array}$ & & & & & & & $\checkmark$ & & & & 1 \\
\hline $\begin{array}{l}\text { 40. Motivating versus demotivating } \\
\text { effects on learners }\end{array}$ & & & & & & & $\checkmark$ & & & & 1 \\
\hline $\begin{array}{l}\text { 41. Not achieving versus achieving } \\
\text { objectives }\end{array}$ & & & & & & & $\checkmark$ & & $\checkmark$ & & 2 \\
\hline $\begin{array}{l}\text { 42. Uncaring versus caring teacher } \\
\text { attitude }\end{array}$ & & & & & & & $\checkmark$ & & & & 1 \\
\hline $\begin{array}{l}\text { 43. Self-directed versus other-directed } \\
\text { teacher focus }\end{array}$ & & & & & & & $\checkmark$ & & & & 1 \\
\hline $\begin{array}{l}\text { 44. Unprepared versus prepared for life } \\
\text { outside classroom }\end{array}$ & & & & & & & $\checkmark$ & & & & 1 \\
\hline $\begin{array}{l}\text { 45. Communicative versus meta- } \\
\text { communicative teaching }\end{array}$ & & & & & & & & $\checkmark$ & & & 1 \\
\hline $\begin{array}{l}\text { 46. Fulfilling versus not fulfilling } \\
\text { purposes of teaching/learning }\end{array}$ & & & & & & & & & $\checkmark$ & & 1 \\
\hline 47. Teacher provides or ignores input & & & & & & & & & $\checkmark$ & & 1 \\
\hline $\begin{array}{l}\text { 48. Initial versus final stages of } \\
\text { learners' language development }\end{array}$ & & & & & & & & & & $\sqrt{ }$ & 1 \\
\hline Total & 4 & 15 & 4 & 8 & 11 & 9 & 10 & 3 & 6 & 8 & 78 \\
\hline
\end{tabular}

The matrix shows the total number of constructs elicited per teacher-trainee (i.e. captured in the bottom row across), the verbal labels used by each of them (i.e. the numbered phrases in the first column), and the teacher-trainees who shared the same verbal labels (see the rightmost column where numbers above 1 indicate the number of teacher-trainees who shared labels). I intentionally refer to 'verbal labels' because although the teacher-trainees often used similar and even the same labels, they might not attach the same meanings to these constructs 
(see Kelly's individuality ${ }^{8}$ and commonality ${ }^{9}$ corollaries in Kelly, 1955: 55-56;91-92; 1966/2003: 9;13-14 $)^{10}$. I concluded that these constructs represent an almost inexhaustible source of topics for further elaboration, critical reflection and awareness-raising talk.

Each prospective teacher received a summary of their constructs like the one below:

Table 3: $\quad$ Constructs list and scenario combinations for Teacher-Trainee 11

\begin{tabular}{|c|c|c|c|}
\hline \multicolumn{4}{|l|}{ Scenarios 1 and 2} \\
\hline Pole A & vs. & Pole B & Commonality \\
\hline Cue-card-based & vs. & Role-defining-card-based & Learning clues \\
\hline Stressful & vs. & Non-stressful & Learning \\
\hline Formal & Vs. & Informal & Interaction \\
\hline Threatening & vs. & Non-threatening & $\begin{array}{l}\text { Learning conditions } \\
\text { [laddered] }\end{array}$ \\
\hline Less & vs. & More & Effective learning \\
\hline Boring & vs. & Fun & Learning \\
\hline Not making & vs. & Making & A difference \\
\hline Uncaring & vs. & Passionate & Attitude \\
\hline \multicolumn{4}{|l|}{ Scenarios 3 and 4} \\
\hline Pole A & Vs. & Pole B & Commonality \\
\hline $\begin{array}{l}\text { Teacher-directed, teacher- } \\
\text { learner }\end{array}$ & vs & $\begin{array}{l}\text { Teacher-prompted, } \\
\text { learner-learner }\end{array}$ & Interactional learning \\
\hline Communicative & vs. & Meta-communicative & Focus \\
\hline Fluency & VS. & Accuracy & Teaching \\
\hline \multicolumn{4}{|l|}{ Scenarios 5 and 6} \\
\hline Pole A & VS. & Pole B & Commonality \\
\hline Challenging & vs. & Not challenging & Your learners \\
\hline Individualised & vs. & Group-based & Critical thinking \\
\hline
\end{tabular}

Table 3: Constructs list and scenario combinations for Subject 11 [Continued]

\begin{tabular}{|l|l|l|l|}
\hline Scenarios 7 and 8 & s. & Pole B & Commonality \\
\hline Pole A & vs. & Dialogue-based & Reflective learning \\
\hline Audio-based & \multicolumn{2}{|l|}{} \\
\hline Scenarios 9 and 10 & vs. & Pole B & Commonality \\
\hline Pole A & vs. & Not-serving & As a role model \\
\hline Serving & vs. & Not identifying & With the teacher \\
\hline Identifying & vs. & Boring & Learning \\
\hline Fun & vs. & Ineffective & Learning \\
\hline Effective & vs. & Not challenging & One's learners \\
\hline Challenging & \multicolumn{5}{|l}{} \\
\hline Scenarios 1 and 4 & vs. & Pole B & Commonality \\
\hline Pole A & vs. & $\begin{array}{l}\text { Teacher-prompted } \\
\text { learner-learner }\end{array}$ & Interaction \\
\hline $\begin{array}{l}\text { Teacher-directed } \\
\text { teacher-learner }\end{array}$ &
\end{tabular}




\begin{tabular}{|c|c|c|c|}
\hline Threatening & Vs. & Non-threatening & Approach \\
\hline \multicolumn{4}{|l|}{ Scenarios 4 and 6} \\
\hline Pole A & vs. & Pole B & Commonality \\
\hline Learner-generated & vs. & Teacher-generated & Language input \\
\hline Participative & vs. & Non-participative & Approach \\
\hline Effective & vs. & Ineffective & Teaching and learning \\
\hline Personalised & vs. & Impersonal & Learner responses \\
\hline Peer-based & vs & Teacher-directed & Interaction \\
\hline \multicolumn{4}{|l|}{ Scenarios 5 and 9} \\
\hline Pole A & vs. & Pole B & Commonality \\
\hline Learner-centred & vs. & Teacher-centred & Approach \\
\hline Having & vs. & Not having & Self-esteem \\
\hline \multicolumn{4}{|l|}{ Scenarios 9 and 6} \\
\hline Pole A & vs. & Pole B & Commonality \\
\hline Committed & vs. & Uncommitted & Learners and teachers \\
\hline Pragmatic & vs. & Non-pragmatic & Approach \\
\hline Keeping & vs. & Losing/Not getting & Learner attention \\
\hline \multicolumn{4}{|l|}{ Scenarios 2 and 7} \\
\hline Pole A & vs. & Pole B & Commonality \\
\hline Multiple & vs. & Single & Roles in exercises \\
\hline Authentic & vs. & Inauthentic & Learning experiences \\
\hline Comprehensive & vs. & Partial & Focus \\
\hline Adequate & vs. & Inadequate & Support for learning \\
\hline Spontaneous & Vs. & Prepared & Responses \\
\hline Unpredictable & vs. & Predictable & Responses \\
\hline \multicolumn{4}{|l|}{ Scenarios 3 and 5} \\
\hline Pole A & vs. & Pole B & Commonality \\
\hline $\begin{array}{l}\text { Teacher-directed teacher- } \\
\text { learner }\end{array}$ & vs. & $\begin{array}{l}\text { Teacher-prompted } \\
\text { learner-learner }\end{array}$ & Interaction \\
\hline Stressful & vs. & Non-stressful & Learning \\
\hline Threatening & vs. & Non-threatening & Conditions of learning \\
\hline Insecure & vs. & Secure & Conditions of learning \\
\hline \multicolumn{4}{|l|}{ Scenarios 3 and 8} \\
\hline Pole A & Vs. & Pole B & Commonality \\
\hline Threatening & vs. & Non-threatening & Conditions of learning \\
\hline Inferencing-absent & vs. & Inferencing-based & Thinking \\
\hline Written & vs. & Spoken & Contributions \\
\hline
\end{tabular}

It is evident from the outline so far that elicitation techniques allow one to gain access to trainees' constructs. ${ }^{11}$ Whether these constructs are looked at from the point of view of the individual (as in the table directly above) or of the collective (where all the constructs are collated), they provide a rich source of topics for further critical-reflective analysis and awareness-raising activities which are rooted in either the individual's or the group's meaning-making processes.

Clearly, the act of externalising the dichotomous constructs by attaching verbal labels to them is in itself an awareness-raising activity. When laddering constructs, we are exploring how the 
preferred poles in our construct systems are configured within complex hierarchies of meaning (see Kelly's organisation corollary, 1955:56-59 and Hill, 1995:101-132). Following Pope and Denicolo (2001:21), I support the view that

we cannot comprehend our own misconceptions, or the limits on our understanding, unless we confront that understanding by first articulating and then contemplating how it could be otherwise.

The elicitation process was two-fold: the prospective teachers were required to infer meanings based on the elicitation schemas, then articulate verbal labels to capture their constructs and configurations of constructs. In the next stage of the project, these constructs were used to design a ratings grid for more in-depth critical-reflective analysis of the groups meaning making.

\subsection{Sequence organisation}

When reviewing the interview discourse, I sensed that a conversation-analytic approach could yield additional perspectives on the data. In this section, I illustrate how the rules for locally managed sequential organisation prompt participants to remain on task and on topic as they co-construct an interactional space in which trainees are required to generate verbal labels for their constructs. The trainees have to meet the cognitive demands of the elicitation frames (i.e. intra-personal action) before they proceed to the social-interactive act of externalising their interpretation of their experience (i.e. inter-personal action) to the trainer. The inter-personal action occurs against the background of the rules that govern how they make relevant, appropriate and co-operative contributions to the discourse.

A sample of the discourse is given to illustrate how these preliminary exchanges, displaying typical sequence organisation, were co-constructed by the participants for scenario combination 1 and $2^{12}$ (see the scenario pairings in Appendix A). The preliminary exchanges in the interview are demarcated by a significant silence in turn 10 .

\section{Sample 1: Eliciting constructs -- Opening sequences and laddering up}

\begin{tabular}{|l|l|l|}
\hline \multicolumn{3}{|l|}{ Turn-by-turn transcription } \\
\hline Turn & Speaker & Turn-by-turn transcription \\
\hline 1 & Trainer & $\begin{array}{l}\text { OK, it's going to be quite simple ...uhm I'm going to ask you to take a } \\
\text { look at those two scenarios/[Non-verbal action: he hands her scenarios 1 } \\
\text { and 2] }\end{array}$ \\
\hline 2 & Subject & /OK/ \\
\hline 3 & Trainer & /you'll see that they come in combinations/ \\
\hline 4 & Subject & OK/ \\
\hline 5 & Trainer & Using pairs, I mean there are 12 of them/ \\
\hline 6 & Subject & OK/ \\
\hline 7 & Trainer & $\begin{array}{l}\text { /So, for each scenario, I'd like you to take a look at them, and first of all, } \\
\text { identify something that is striking to you. If you take a look at the two of } \\
\text { them ... take a look at one of them and if you find something unique that } \\
\text { appeals to you, identify that something, let's start there/ }\end{array}$ \\
\hline 8 & Subject & OK, so it can be a difference in both / of them \\
\hline
\end{tabular}




\begin{tabular}{|l|l|l|}
\hline 9 & Trainer & It could be anything different/ \\
\hline 10 & Subject & $\begin{array}{l}\text { [significant silence as she reads }-20 \text {-second silence as processing time, } \\
\text { with trainer saying midway through time: You can take your time... } \\
\text { there's no rush, you have an hour.] } \\
\text { OK, with scenario 2 what I like is that it's... there's no preparation time/ }\end{array}$ \\
\hline
\end{tabular}

These preliminaries show that the trainer, as a primary knower, employs statement-turn components to outline the constructs elicitation task (see turns 1, 3, 5, 7 and 9 above). The trainee, as a secondary knower, employs continuity signals such as $O K$ (see turns 2, 4 and 6) as online feedback to the interviewer that the task outline has been understood. In turn 8 , the trainee uses a checking lingual act to confirm that she has understood the task ${ }^{13}$. In the next phase of the discourse, the trainee responds ${ }^{14}$, using statement-turn components in a role switch, where she is now the primary knower. ${ }^{15}$

Sample 2: Knower status and turn-constructional units

\begin{tabular}{|l|l|l|}
\hline \multicolumn{2}{|l|}{ Turn-by-turn transcription } \\
\hline Turn & Speaker & Turn-by-turn transcription \\
\hline 10 & Subject & $\begin{array}{l}\text { [significant silence as she reads - 20-second silence as processing time; } \\
\text { trainer says midway through time: You can take your time... there's no } \\
\text { rush, you have an hour.] OK, with scenario 2 what I like is that it's there's } \\
\text { no preparation time/ }\end{array}$ \\
\hline 11 & Trainer: & Yeah, OK/ \\
\hline 12 & Subject & And almost it's... it's a real-life response because it's a real-life situation/ \\
\hline 13 & Trainer & Uhm, yeah/ \\
\hline 14 & Subject & That's unique to me there/ \\
\hline 15 & Trainer & $\begin{array}{l}\text { OK, let's stop at that point. I mean, that is an interesting feature. Is that an } \\
\text { important feature to you? }\end{array}$ \\
\hline 16 & Subject & Yes, I think it is because that's what language is all about, it's not about/ \\
\hline 17 & Trainer & Uhm/ \\
\hline 18 & Subject & Most of all it's about communication and enabling/ \\
\hline 19 & Trainer & Uhm/ \\
\hline 20 & Subject & $\begin{array}{l}\text { the learners to be able to speak and to be able to communicate on the spur } \\
\text { of the moment/ }\end{array}$ \\
\hline 21 & Trainer & Yeah/sure \\
\hline 22 & Subject & To uhm... to uhm... because especially if it's a second language/ \\
\hline 23 & Trainer & Yes/ \\
\hline 24 & Subject & $\begin{array}{l}\text { You think in your first language and then you speak in your second } \\
\text { language, /so }\end{array}$ \\
\hline 25 & Trainer & Yes/ \\
\hline 26 & Subject & $\begin{array}{l}\text { To do it on the spur of the moment }- \text { it requires of them to be able to really } \\
\text { you know, interpret or invert everything in their minds/ }\end{array}$ \\
\hline 27 & Trainer & Yes/ \\
\hline 28 & Subject & Very quickly/ \\
\hline
\end{tabular}


The trainer has become the note-taker and secondary knower who records the meaning making of the trainee. Interestingly, in turn 15, the trainer, as superordinate in the authority relationship, invokes his role as task manager, who has the right to talk about the importance of the meanings the trainee has assigned to the two scenarios. However, the trainer remains in the secondary-knower role; in turn, the trainee embarks upon a series of elaborative statement-turn components, interspersed with continuity signals such as yeah, uhm, $O K$ and yes ${ }^{16}$ from the trainer. At the 'transition relevance place' in turn 29, the trainer again invokes the task manager role to elicit the opposite of what the learner has said so far. The preferred and opposite poles of the constructs can be demonstrated in a hierarchical flowchart such as the following:

Table 4: Construct networks

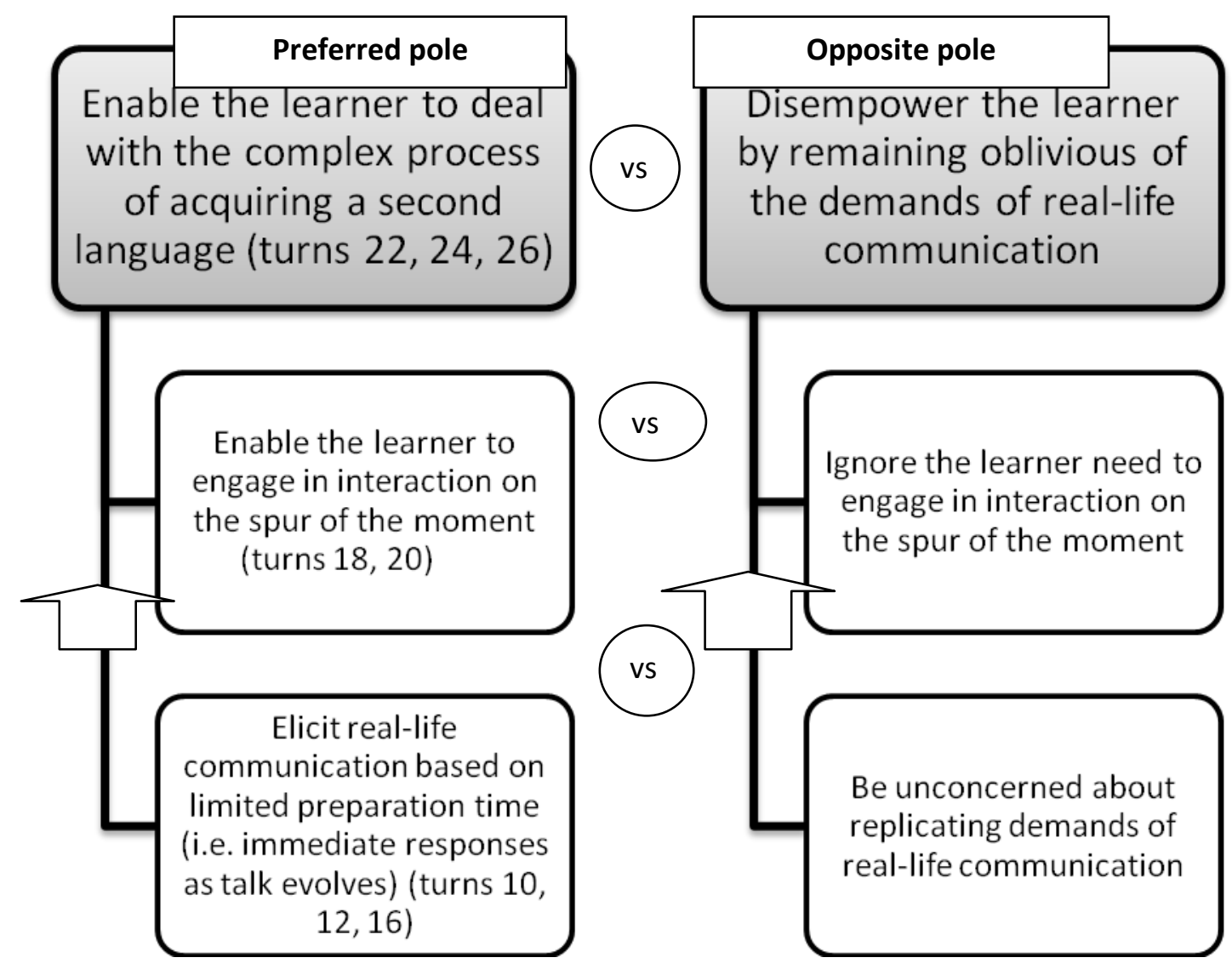

However, it is worth noting that the interactional exchanges contain significant actions. The pre-sequences (turn 1 to 9) define the constructs-defining task, the inferencing required to respond appropriately to the task, as well as the 'mentionables' that will qualify as part of an appropriate multi-turn, second-pair part (turns 10 and 12), interspersed with two continuity signals produced by the trainer (turns 11 and 13). Following the laddering schema, the trainer engages in a schema-derived, first-pair part (turn 15). This first-pair part is again followed by a multi-turn, second-pair part (turns 16, 18, 20, 22, 24, 26, and 28), interspersed by trainerproduced continuity signals such as uhm, yeah, sure, and yes. These continuity signals seem to be interpreted as prompts to the interviewee that the next turn is allocated to her. Thus, continuity signals are used to allocate the next turn in terms of their being interpreted as 'tellme-more, continue-with-current-turn' speaker allocation. Interestingly, the 'tell-me-more, 
continue-with-current-turn' speaker allocation may be interpreted as an interactional equivalent for the why-question in the laddering schema. ${ }^{i}$

The conclusion was drawn that CA perspectives could be used to raise awareness of how the cognitive demands of the elicitation frames were reflected in the social-interactive process of externalising constructs. Moreover, the teacher-trainer, as interviewer, has the right to design activity-specific interactional floors, imposing interview-specific sequence organisation for awareness-raising purposes (Dorr-Bremme, 1990:379-402; Greyling, 2005: 188; Jones \& Thornborrow, 2004:399-423; Marcondes de Souza, 1983:49; McHoul, 1978:188).

\section{CONCLUSION}

The results of the study show that dyadic construct elicitation and laddering are techniques that may allow teacher-trainers to elicit a rich data-base of the teaching- and learning-related constructs informing teacher-trainees' meaning-making. During the construct-elicitation process, the participants commit to reflecting on their experience and articulating verbal labels that reflect their constructs. Trainees have to process the scenario events before making discursively relevant multi-turn contributions consistent with the sequential organisation of dyadic talk. Such contributions have to comply with the teacher-trainer's design of activityspecific sequence organisation for this particular interview discourse type. Specifically, at the start of the interview, the interviewer establishes the rules of the meaning-making process, directing the interviewee's responses by means of the initial pre-sequences, and initiating iterative cycles typically associated with the elicitation and laddering techniques. Within the parameters of sequential organisation, participants engage in critical-reflective talk about the constructs that helps to steer their meaning making, with the trainer and the trainees often switching between primary and secondary knower status. The discursive processes involve talk about meaning making and require subjects to make relevant, on-topic and on-task contributions in which they engage in meta-talk.

Conversation-analytic tools allow researchers to judge how authentic the dyadic exchanges are, specifically within the turn-by-turn demand of making relevant next-turn contributions and the more global demand of making contributions to the discourse which adhere to the trainer-designed sequence organisation. This first stage of the project provided the constructs and set the scene for designing a repertory grid for the cohort to be used in stages 2 and 3 of the project. All in all, the interview-based, construct-elicitation process, proved to be a significant first step in the awareness-raising process. It should further be noted that reviews of the recorded interview processes provide evidence that the social-interactive demands of the trainer-trainee interviews reinforce the process of raising teacher-trainees' awareness of their classroom-related constructs.

The purpose was to raise these prospective language teachers' awareness of their constructions, and to show that these individual configurations of personally held meanings impact on the way they create interactional spaces, define roles and structure experiences for their learners. All teachers need to raise their awareness of the meanings they - and others place on their experiences. Their raised awareness allows them to explore the options open to them to develop new roles and practices (Cranton, 2006:20-24) and to analyse how they develop critical-reflective skills while engaging in classroom action or after the event (Fenwick \& Tennant, 2004:60-65) and how meanings are expressed in micro-level 
interactional exchanges that relate to participants' identities and the relationships of power that obtain among them (Mayes, 2010:189-210).

Acknowledgements: I would like to thank final year students in two language teaching methods modules (2008) in the Faculty of Education at the institution for their willingness to participate. They were not only willing to engage, but also agreed to modify the assessment structures of the modules to embed the research project. I would also like to acknowledge the-then vice-dean, Professor Engela Pretorius, for her guidance and role in making the project possible. Finally, I would like to thank Albert Weideman, Susan Brokensha, Colleen du Plessis, the editor of Per Linguam, and two anonymous reviewers for their comments and suggestions for changes to the text.

\section{ENDNOTES}

1. For all communications about this article, contact the author at the e-mail address listed above.

2. My initial aim was to use Kelly's ratings repertory grid (Adams-Webber, 2003; Bell, 2003; Denicolo, 2003; Fransella, 2003; Fransella, Bell \& Bannister, 2004; ) as an awareness-raising tool; however, I soon discovered that the preliminary qualitative processes of eliciting and laddering the cohort's classroomrelated constructs constituted collaborative sessions in which trainees' meaning making became focal objects of study. Stage 2 involved devising a ratings grid, eliciting ratings, processing these results in SPSS (Statistical Package for the Social Sciences), and then formulating tentative hypotheses for each subject based on the correlations between the constructs entered into the grid (Greyling, 2011:167-192). Stage 3 involved individualised feedback to each student, as well as aggregated group-based findings. Stage 4, the last stage, required students to respond in writing to the tentative hypotheses, as well as two problem-based tasks (see Murphey \& Falout, 2010:811-821; Silverman, 2010:189-310).

3. Personal construct theory practitioners have a range of elicitation techniques available to them. These include single, dyadic and triadic elicitation, as well as self-characterisations, analysis of written materials, the use of non-verbal prompts, and computer-based elicitation (Denicolo \& Pope, 2001; Fransella, 2003; Fransella, Bell \& Bannister, 2004:27-39; Pope \& Denicolo, 2001;).

4. Kelly's view of the person is positive: any person will choose those anticipations of the future that will optimally support his/her future-directed meaning making. As Hinkle (1965:2) stated: "Kelly's psychology 'assumes that a man is not condemned by his past history ... [a]s such it aspires to be 'a psychology of the optimal man' - not the minimal man, but the optimal man - man in the process of being human'.

5. Dyadic elicitation refers to the elements used in the elicitation process. Although Kelly's definition refers to three 'events', Fransella, Bell and Bannister (2004:27-30) pointed out that elicitation may involve triadic, dyadic or single elements. In this project, I did not use role titles as elements; instead, I used brief three- to five-sentence scenarios as prompts or in Kelly's terms, elements, in 12 random pairings, to elicit constructs in the trainer-trainee interviews.

6. Using laddering as an elicitation technique involves some risk. For the concerns related to this technique, I recommend Fransella, Bell and Bannister (2004:40-43).

7. In this post-hoc review, Ifollowed a typical conversation-analytic methodology: I transcribed sections of five interviews, specifically sequences dealing with the elicitation process. This formed the basic data for a posthoc analysis. Upon identifying a specific pattern, I re-examined the basic data set to validate the soidentified pattern. Moreover, I then returned to the full data set, closely examining it again, for further validation of the interactional patterns or features I had described (Silverman, 2010:189-310).

8. The individuality corollary states that individuals differ from each other in terms of the distinct meanings they assign to their experience. In Kelly's words, the corollary refers to the fact that 'persons differ from each other in their constructions of events' (Kelly, 1955:55-56).

9. The commonality corollary refers to shared forms of meaning making between individuals. This corollary, Kelly (1955:90) stated, implies that 'to the extent that one person employs a construction of experience which is similar to that employed by another, his psychological processes are similar to those of the other person'.

10. Greyling (2008) observed that a cohort of prospective teachers assigned a wide range of meanings to the concept 'discursive initiative' in classroom exchanges.

11. The laddered construct (marked with a downward arrow in Table 3) yielded the following meaning making, which was paraphrased as follows: "Why is non-threatening learning important to you? It is important to me because it is more effective. Why is it important to you that learning is effective? If it's effective, it's fun. Why is that important to you? If it's non-threatening, effective and fun, one is making a difference. Why is that important to you? I am passionate about language teaching, that's why I want to make a difference." 
12. When I wrote these scenario combinations, I consciously and purposely wrote them to cover pedagogical principles in action in classroom contexts. Thus, I constructed them on the basis of constructs I had encountered in applied linguistics, ELT and related literature. For example, in my constructions, scenario 1 represents teacher-mediated learning in the main discourse of the classroom, while scenario 2 is a teacherdesigned space for role-based interactional learning among learners. Both are forms of teacher control; however, scenario 1 shows teacher control over the discourse in an extended sequence of interactions, while scenario 2 represents teacher control in the form of her designing a simulation of a real-life interactional space in which learners participate in a problem-solving task. In scenario 1, the teacher restricts learner initiative to their having to respond to known-information questions, while in scenario 2 the teacher designs a learning space for learners to take optimal initiative in producing coherent and cohesive goal-directed discourse.

13. Once the procedure for completing the task had been established, when a new scenario combination was introduced, the interviewer employed a one-line prompt to elicit the exchange pattern:

Turn 71 Trainer: Let's go onto the next one.

Turn 72 Subject: (Silence)

So, the procedure, negotiated in the preliminary exchanges at the start of the interview, had become common ground; thus, in all subsequent exchanges the elicitation process was initiated by a one-line prompt. Moreover, the co-ordinated statement-turn components, the continuity signals and the checking lingual act constituted evidence of a co-operative discursive process in which the participants co-ordinated their contributions in task-directed exchanges. It should be noted too that much time was spent in a lecture context to ask why-questions to ladder up. In the interviews, the students needed very little prompting to activate related constructs, often with a non-verbal directing act as a prompt. Perhaps it would be fair to argue that the routine had already been established prior to the interview stage.

14. The learner response, produced over several turns after the significant silence, took the form of statementturn components relevant to the elicitation task.

15. The distinction primary versus secondary knower may be found in Berry (1981). The distinction captures a commonsense notion that if a person has relevant background knowledge or knows the information covered in an exchange, such a person is the primary knower. The converse is also true: if a person does not have such knowledge, the person is a secondary knower.

16. In turns 10 to 14 , the trainee activates the following constructs: 'learners having no preparation time' versus 'learners having preparation time' to produce responses; 'real-life-like' versus 'inauthentic' responses; and 'simulating' versus 'neglecting real-life situations in learning'. The trainer then prompts the trainee, in turn 15 , as part of laddering-directed questioning, to elaborate on why this feature is important to her. In turns 16 to 28 , she explores the whys of the position she has taken.

17. In brief, the sequence organisation followed a specific pattern. First, at the start of the interview the trainer would use pre-sequences to establish the framework for making relevant contributions to the interview discourse. Second, these pre-sequences were followed by a significant silence required for cognitiveprocessing time. Next, the trainees used statement-turn components to externalise the verbal labels for their constructs following the dyadic elicitation frame, followed by why-questions and relevant statement-turn components. On completion of the elicitation process for a scenario combination, the next scenario combination would be initiated with a prompt (without the first step referred to above). I found this iterative process to occur throughout the recorded discourse.

\section{REFERENCES}

ADAMS-WEBBER, J. 2003. Research in personal construct psychology. In Fransella, F. (Ed.). International handbook of personal construct psychology. Chichester, UK: John Wiley \& Sons. 51-58.

BELL, RC. 2003. The repertory grid test. In Fransella, F (Ed.), International handbook of personal construct psychology. Chichester, UK: John Wiley \& Sons . 95-103.

BERRY, M. 1981. Systemic linguistics and discourse analysis: A multi-layered approach to exchange structure. In Coulthard, M \& M Montgomery (Eds). Studies in discourse analysis. London, UK: Routledge \& Kegan Paul. 120-145. 
BORG, M. 2003. Teacher cognition in language teaching: A review of research on what language teachers think, know, believe, and do. Language Teaching. 36:81-109.

CRANTON, P. 2006. Understanding and promoting transformative learning - a guide for educators. ( $2^{\text {nd }}$ ed). San Francisco, CA: Jossey-Bass.

DENICOLO, P. 2003. Elicitation methods to fit different purposes. In Fransella, F. (Ed.), International handbook of personal construct psychology. Chichester, UK: John Wiley \& Sons. 123-131.

DENICOLO, P \& M POPE. 2001. Transformative professional practice. Personal construct approaches to education and research. London, UK: Whurr.

DORR-BREMME, DW. 1990. Contextualization cues in the classroom: Discourse regulation and social control functions. Language in Society, 19:379-402.

FENWICK, T \& M TENNANT. 2004. Understanding adult learners. In Foley, G. (Ed). 2004. Dimensions of adult learning. Adult education and training in a global era. Maryborough, Victoria, Australia: Allen \& Unwin. 55-73.

FRANSELLA, F. 1989. What is a personal construct? Taken from Lane, DA (Ed.). Attributions, beliefs and constructs in counselling psychology, Counselling Psychology Section: British Psychological Society Occasional Paper, as part of course materials for the short course, The Basics of Personal Construct Psychology and Its Methods of Inquiry, offered by the Centre for Personal Construct Psychology, University of Hertfordshire, UK.

FRANSELLA, F. (Ed.). 2003. International handbook of personal construct psychology. Chichester, UK: John Wiley \& Sons.

FRANSELLA, F., R BELL \& D BANNISTER. 2004. A manual for repertory grid technique. Chichester, UK: John Wiley.

FREEMAN, D. 2002. The hidden side of the work: Teacher knowledge and learning to teach. Language Teaching. 35:1-13.

GREYLING, WJ. 2005. Constructing interactional floors for language learning ends: Reflecting on a teacher-upgrading course. Journal for Language Teaching, 39(2):187208.

GREYLING, WJ. 2008. Exploring prospective language teachers' constructions of 'discursive initiative': Generating hypotheses about their thinking. Journal for Language Teaching, 42(2):43-61. GREYLING, WJ. 2011. Raising awareness of classroom constructs: An application of Kelly's repertory grid technique. Acta Academica. 43(3):167-192.

HILL, RA. 1995. Content analysis for creating and depicting aggregated personal construct derived cognitive maps. In Neimeyer, RA \& GL Neimeyer (Eds). Advances in personal construct psychology. Greenwich, CT: Jai Press. 101-132.

HINKLE, DN. 1965. The change of personal constructs from the viewpoint of a theory of construct implications. Unpublished doctoral thesis. The Ohio State University, Columbus, Ohio.

JONES, R \& J THORNBORROW 2004. Floors, talk and the organization of classroom activities. Language in Society, 33:399-423. 
KELLY, GA. 1955. The psychology of personal constructs. Volumes 1 and 2. New York, UK: W.W. Norton.

KELLY, GA. 1966/2003. A brief introduction to personal construct theory. In Fransella, F. (Ed.), International handbook of personal construct psychology. Chichester, UK: John Wiley \& Sons. 3-20.

LEVINSON, SC. 1983. Pragmatics. Cambridge, UK: Cambridge University Press.

MARCONDES DE SOUZA, D. 1983. Action-guiding language. Journal of Pragmatics, 7:4962.

MAYES, P. 2010. The discursive construction of identity and power in the critical classroom: Implications for applied critical theories. In Discourse and society, 21(2):189-210.

McHOUL, A. 1978. The organization of turns at formal talk in the classroom. Language in Society, 7(2):183-213.

MEY, JL. 1993. Pragmatics - an introduction. Oxford, UK: Blackwell.

MURPHEY, T \& J FALOUT. 2010. Critical participatory looping: Dialogic member checking with whole classes. TESOL Quarterly, 44(4):811-821.

POPE, M. 2003. Construing teaching and teacher education worldwide. In Fransella, F. (Ed.), International handbook of personal construct psychology. Chichester, UK: John Wiley \& Sons. 303-310.

POPE, M \& P DENICOLO. 2001. Transformative education. Personal construct approaches to practice and research. London, UK: Whurr.

SALMON, P. 2003. A psychology for teachers. In Fransella, F. (Ed). International handbook of personal construct psychology. Chichester, UK: John Wiley \& Sons. 311-318.

SCHEGLOFF, E. 2007. Sequence organization in interaction. A primer in conversation analysis. Volume 1. Cambridge, UK: Cambridge University Press.

SILVERMAN, D. 2010. Doing qualitative research. (3rd ed.) Los Angeles, CA: Sage.

STATISTICAL PACKAGE FOR THE SOCIAL SCIENCES. SPSS 17.0. Available athttp://www.spss.com

TEN HAVE, P. 2000. Doing conversation analysis. A practical guide. London: SAGE.

TSUI, ABM 2007. Complexities of identity formation: A narrative inquiry of an EFL teacher. TESOL Quarterly. 41(4):657-680.

VAN LIER, LAW. 1996. Interaction in the language curriculum. Awareness, autonomy \& authenticity. London, UK: Longman.

WHITE, M. 1995. Re-authoring lives: Interviews \& Essays. Adelaide, Australia: Dulwich Centre.

WOODS, D. 1996. Teacher cognition in language teaching. Beliefs, decision-making and classroom practice. Cambridge, UK: Cambridge University Press. 


\section{BIOGRAPHICAL NOTE}

Wilfred Greyling is currently appointed as Research Associate in the Department of English at the University of the Free State, Bloemfontein.

Email address: Wilfred.Greyling@wintec.ac.nz 


\section{APPENDIX A: SCENARIO COMBINATIONS (Elements)}

[Pairings used: 1 and 2; 3 and 4;5 and 6; 7 and 8; 9 and 10; 1 and 4; 4 and 6;5 and 9;6 and 9; 2 and 7 ; and 3 and $5 ; 3$ and 8$]$

Scenario 1: The teacher asks questions about word meanings in a text. Learners are unable to answer a specific question whose answer the teacher knows. The teacher provides clues, re-initiates and rephrases. Eventually learners arrive at the answer.

Scenario 3: This is a teacher-led discussion of a contentious issue: the teacher invites learner opinions, and then interrogates learner opinions by asking incisive questions. Learners are required to think carefully about the positions they take.

Scenario 5: The teacher provides learners with a mind-map of all the possibilities in English to argue a case. She gives an example of how to argue a case. She then instructs learners that they have to use the mind-map as an aid in arguing a case for HIV counselling in schools

Scenario 7: The teacher initiates an exercise in which learners are required to talk about a dialogue they had produced and audiorecorded some time earlier. Learners have to judge the grammar and the appropriateness of the utterances in terms of role and context.

Scenario 9: My view of what I would like to be like as an ideal teacher.
Scenario 2: The teacher uses a role-play exercise where specific roles are allocated. The details of each role are specified on a cue card. Then, the teacher reads a specific real-life problem to the learners. They are given no preparation time, and are required to solve the problem on the spur of the moment.

Scenario 4: The teacher writes a dialogue, and then scrambles the line of the dialogue. She then asks learners to find the most appropriate sequence of turns. They use English to talk about the appropriateness of the sequence of turns.

Scenario 6: My view of my current teaching style, beliefs and thinking about teaching.

Scenario 8: The teacher structures a reasoning gap where learners have to consider the implications of the following what-if statement: What if human beings had nerve endings in their hair? Students work in pairs, exploring the implications.

Scenario 10: Learners are provided with the first two lines of a dialogue. They have to discuss the context in which these utterances have occurred, and they have to add on ten turns-at-talk. 